\title{
Review \\ Proteinopathy-induced neuronal senescence: a hypothesis for brain failure in Alzheimer's and other neurodegenerative diseases
}

Todd E Golde and Victor M Miller

1Department of Neuroscience, Mayo Clinic, Mayo Clinic College of Medicine, 4500 San Pablo Road, Jacksonville, Florida 32224, USA

Corresponding author: Todd E Golde, tgolde@mayo.edu

Published: 13 October 2009

This article is online at http://alzres.com/content/1/2/5

(c) 2009 BioMed Central Ltd
Alzheimer's Research \& Therapy 2009, 1:5 (doi:10.1186/alzrt5)

Genetic, pathological, biochemical, animal and cell modeling studies provide strong support for the general hypothesis that accumulation of misfolded, aggregated proteins in the brain triggers a complex series of events that result in neuronal degeneration [1-4]. In Alzheimer's disease (AD) aggregation and accumulation of the amyloid $\beta$ (AB) protein and microtubule associated protein tau (MAPT) have both been implicated as key pathogenic 'triggers' [5]. A $\beta$ accumulates in senile plaques, cerebral vessels, and, to a more limited extent, within neurons [6]. Tau accumulates inside cells as neurofibrillary tangles and tau neurites [7]. In genetic forms of $A D$ the data overwhelmingly support the ' $A \beta$ aggregate/amyloid cascade' hypothesis, which posits that $A \beta$ aggregation and accumulation precedes, and therefore drives, tau accumulation [3]. In 'sporadic' cases it is also possible that the two pathologies may arise, at least in part, through independent pathways [8]. Like familial $A D$, mutations in a number of genes result in accumulation of protein aggregates (for example, ABri, ADan, superoxide dismutase, $\alpha$-synuclein, huntingtin, ataxins, and neuroserpin), triggering the pathological cascade that leads to many phenotypically distinct neurodegenerative diseases $[1-3,9,10]$.

Herein, we will refer to the generic concept of misfolded protein aggregation and accumulation as a proteinopathy. Although there is reasonable consensus in the field regarding proteinopathies as 'triggers' of neurodegeneration, there is little consensus regarding the mechanisms that lead to neuronal demise. Using the $A \beta$ and tau proteinopathies in $A D$ as examples, we will present an integrated hypothesis of how central nervous system (CNS) proteinopathies cause neurodegeneration through a cascade initially involving innate immune activation, inflammation, induction of senescence,

$\mathrm{A} \beta=$ amyloid $\beta ; A D=$ Alzheimer's disease; $C N S=$ central nervous system; IL = interleukin; MAPT = microtubule associated protein tau; $M C P=$ monocyte chemoattractant peptide; $\mathrm{MHC}=$ major histocompatibility complex; PAMP = pathogen-associated molecular pattern; PRR = pattern recognition receptor; SASP $=$ senescence-associated secretory phenotype; SMS $=$ senescence-messaging secretome; TI- $2=$ thymus independent type 2. 


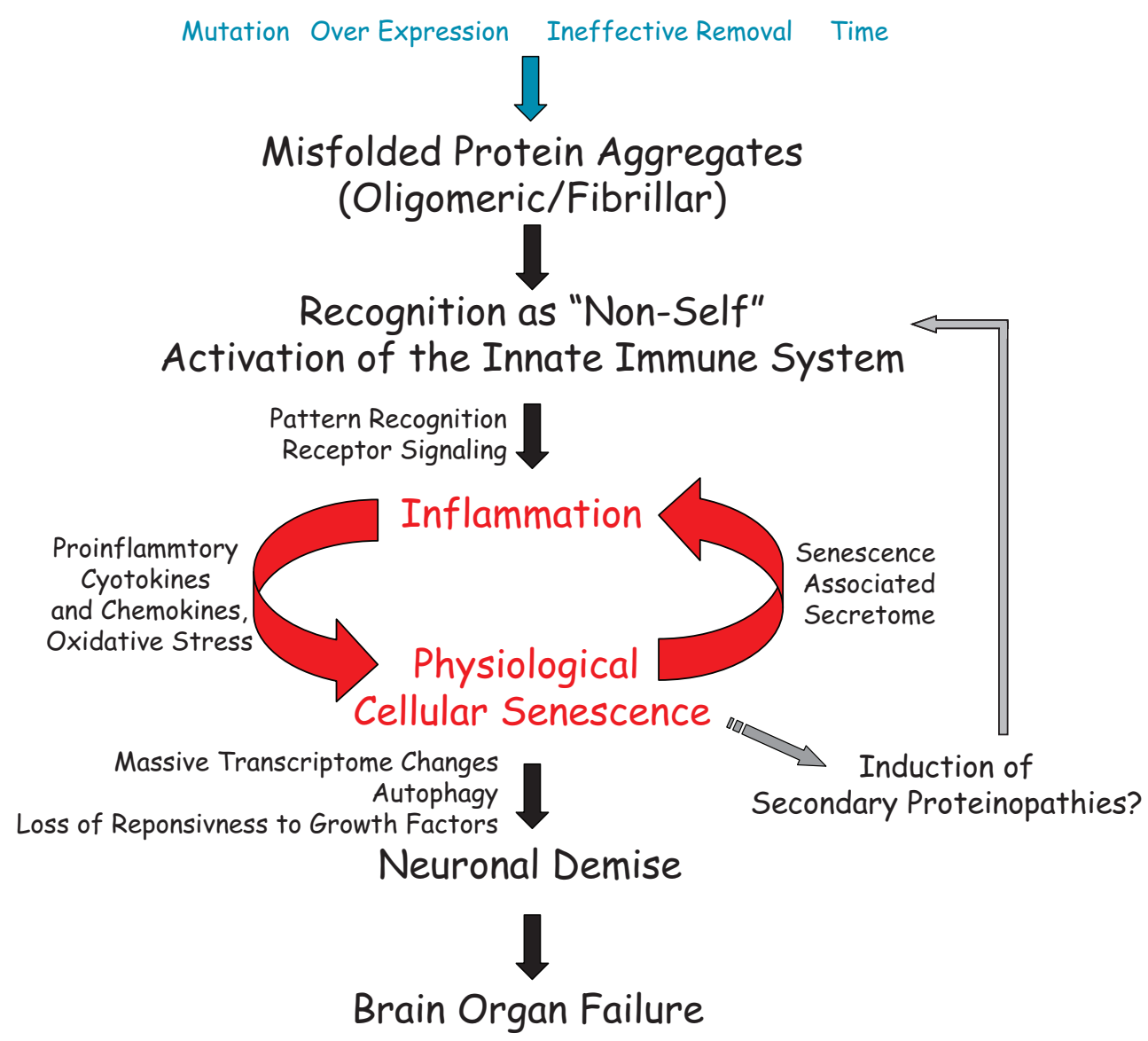

Proteinopathy-induced neuronal senescence. A schematic of proteinopathy-induced neuronal senescence depicts protein misfolding and aggregation as a trigger for a self-reinforcing cycle of pro-inflammatory signals and senescence. As a critical mass of neurons acquire a physiologically senescent phenotype overt neurodegeneration and failures in the brain's cognitive and regulatory functions become clinically apparent.

and subsequent neurodegeneration. We will refer to this integrated hypothesis as the proteinopathy-induced senescent cell hypothesis of neurodegeneration (Figure 1). Along with a detailed presentation of the hypothesis and current experimental data that support this hypothesis, we will outline the experimental steps needed to validate this hypothesis and explore its potential significance with respect to therapeutic development for $A D$ and other neurodegenerative proteinopathies.

\section{Step 1: misfolding and aggregation of proteins into pathogen associated molecular patterns}

$A \beta$, tau and other protein aggregates in neurodegenerative diseases are almost always found in an abnormal structural conformation compared to the non-aggregated protein [1-4]. Many aggregates show the characteristic features of amyloid and accumulate in an 'abnormal' fibrillar $\beta$-pleated sheet structure [11]. A common theme of genetic alterations that cause $A D$ is that they increase the likelihood that $A \beta$ will aggregate into amyloid [6]. Mutations in tau that cause frontal temporal dementia with parkinsonism linked to chromosome 17 (FTDP-17 MAPT) also alter tau in a way that increases its likelihood to aggregate into amyloid-like structures [12-14]. Furthermore, there is evidence that mutations in, or overexpression of, other proteins linked to neurodegeneration enhance the likelihood that they are assembled into misfolded aggregates, and many of these aggregates also have characteristic features of amyloid [1-4].

When a normal protein misfolds and aggregates, it no longer resembles a self protein; thus, it is subject to recognition by the immune system. Misfolded self protein aggregates resemble pathogen-associated molecular patterns (PAMPs) and thymus independent type 2 (TI-2) antigens [15-18]. PAMPs are a group of molecules that are capable of activating a wide array of innate immune defenses. They can be proteins, polysaccharides, or nucleotides and are charac- 
terized by a repetitive molecular motif that is recognized as non-self and can bind and activate evolutionarily conserved pattern recognition receptors (PRRs) that initiate innate immune signaling. Classic PAMPs are bacterial lipopolysaccharide, flagellin, peptidoglycan, some viruses and viruslike particles, and double-stranded RNA. TI-2 antigens are similar polymeric molecules that directly stimulate $B$ cells to secrete IgM by crosslinking of plasma membrane immunoglobulin. Despite their chemical diversity, the unifying features of both PAMPs and TI-2 antigens are that they are large in size (typically greater then $100 \mathrm{kDa}$ and often much larger), and have repetitive epitopes (and at least for TI-2 antigens require rigid presentation of the epitope with a twodimensional spacing of 5 to $10 \mathrm{~nm}$ ), poor in vivo degradability, and the ability to activate complement [18]. Notably, these features of PAMPS and TI-2 antigens are quite reminiscent of the features of amyloid deposits [11].

Misfolded protein aggregates can theoretically activate the adaptive immune system. However, the key step in activation of adaptive immunity, major histocompatibility complex (MHC) presentation of non-self peptides, is likely to limit such activation [19]. MHC binds small peptides that are typically cleaved from a larger protein [20]. Unless a small peptide derived from the protein aggregate retains an abnormal 'nonself' configuration following disaggregation, proteolytic cleavage, and binding to the $\mathrm{MHC}$, it will not be a strong activator of the adaptive immune system [21]. Moreover, classic MHC molecules are typically expressed at low levels in the CNS and though there clearly is continuous surveillance of the CNS by $\mathrm{T}$ cells, the low levels of $\mathrm{T}$ cells and limited $\mathrm{MHC}$ expression are likely to limit adaptive immune responses to misfolded self proteins in the CNS. Thus, misfolded self protein aggregates are not likely to strongly activate the adaptive immune response. Instead, the proteinopathy will largely activate the innate immune system.

The recent description of proteins that can exist as functional amyloid-like structures within select organelles challenges, to some degree, the notion that all aggregated misfolded proteins are PAMPs. Examples of physiologically 'functional' mammalian amyloids are currently limited to amyloid formation by select peptide hormones in secretory granules of the pituitary, amyloid present in semen, and Pmel17 in melanocytes [22-24]. Notably, both the secretory granule amyloid and Pmel17 amyloid are contained within intracellular vesicles that most likely sequester them from interaction with PRRs and other forms of innate immune surveillance. Furthermore, because the peptide hormone amyloids must dissociate in order for them to be active, they are distinct from many pathological amyloids and PAMPs, which are highly stable structures.

\section{Step 2: proteinopathy-mediated activation of innate immunity results in chronic inflammation} Amyloid or amyloid-like protein aggregates are highly resistant to degradation [11]. Perhaps the clearest illustration of this stability is seen in both in vivo imaging studies in $A \beta$ protein precursor transgenic mice and cross-sectional pathology studies in inducible $A \beta$ protein precursor transgenic mice [25-28]. These studies demonstrate that the amyloid deposits, once formed, are incredibly stable even in the absence of ongoing $A \beta$ production. Though intracellular aggregates, such as those found in the polyglutamine diseases, can in certain circumstances be cleared in mice in which the transgene is turned off entirely, this situation is not replicated in the human disease and attempts to clear the aggregates may result in direct impairment of the protein quality control machinery [29-32]. Significantly, amyloid or amyloid-like protein aggregates catalyze the structural conversion of the normally folded protein into additional aggregates via a seeded nucleation-dependent process. Thus, following nucleation, the ongoing production of a 'normal' precursor drives additional amyloid formation $[33,34]$. In contrast to amyloid, the stability and 'seeding' or nucleating potential of other potentially pathogenic oligomeric structures formed by misfolded proteins has not been studied in detail $[35,36]$.

We postulate that extracellular and intracellular protein aggregates act like PAMPs and result in chronic activation of the innate immune systems through PRRs. The concept that misfolded protein aggregates are PAMPs and activate innate immunity has been previously suggested by a number of groups and is supported by a plethora of experimental data [37-39]. Amyloid and amyloid like aggregates regardless of their peptide or protein subunit can be shown to bind and activate a whole array of PRRs, including Toll-like receptors, formyl peptide receptors, receptor for advanced glycation end products, scavenger receptors, complement and pentraxins [37-39]. Oligomeric assemblies of amyloidogenic proteins have not been studied as intensively with respect to PRR activation, but in the cases that they have they can be shown to elicit effects similar to amyloid fibrils (reviewed in [37]). Structurally, it is likely that oligomeric proteins resemble viruses or virus-like particles, which are known to function as PAMPs [40].

Most of the experiments that have established amyloid, amyloid like structures, and oligomers as PAMPs have involved direct application of these aggregates to cells in culture [37]. Such studies are complemented by histopathological studies that show co-localization of inflammatory cells and mediators with amyloid plaques and in vivo studies using multiphoton imaging that show the rapid mobilization of microglia to newly formed plaques [38,39,41-43]. These studies strongly support the concept that extracellular proteinopathies activate PRRs. Less well supported by direct experimental data is the notion that an intracellular protein aggregate acts like a PAMP, resulting in activation of PRRs and mobilization of the innate immune defenses. Nevertheless, a number of pathological features seen in intracellular proteinopathy-induced neurodegeneration suggest that these 
intracellular aggregates are activating the innate immune system. For example, binding to heat shock proteins, induction of autophagy and binding to intracellular PRRs can all activate the innate immune system [37,44-46].

The notion that intracellular proteinopathies activate innate immunity incorporates and extends some aspects of the danger theory of immune activation. This theory postulates that an intracellular stress or pathogen results in the cell generating a 'danger' signal that activates the immune system [47]. In this case we postulate that an intracellular protein aggregate causes the neuron or other CNS cell to send out 'danger signals' that activate the innate immune system. Such 'danger signaling' might explain the observation that inflammatory markers are often the earliest sign of pathology in experimental models of neurodegenerative proteinopathies [38,48-51]. Ultimately, intracellular or extracellular, stable protein aggregates acting as PAMPs will produce a chronic inflammatory condition.

A major ongoing debate in the $A D$ and the larger neurodegenerative disease field is whether small soluble aggregates or larger, less soluble aggregates are the principle toxic species [52-55]. In the context of this hypothesis, both small soluble aggregates - oligomers - and larger aggregates fibrils - will function as PAMPs. Depending on their concentration, location, and degradability, their ability to activate PRRs will likely vary. Significantly, the activation of PRRs by PAMPs elicits a response that is designed to result in clearance or sequestration and inactivation of the PAMP. In addition to a whole host of other variables, differential activation of the innate immune system by different protein aggregates and variable clearance of the aggregates following immune activation probably contribute to the imperfect correlations between the amounts and regional distribution of protein aggregates with clinical and neuropathological phenotypes [56]. Indeed, an aggregate that elicits the strongest innate immune response may be cleared more effectively. If this is the case, then it will always be challenging to link the aggregate to downstream pathology through cross-sectional analyses.

\section{Step 3: chronic inflammation and senescence are mutually reinforcing states}

Histopathological, biochemical and molecular studies unambiguously show that the $A D$ brain is subject to a chronic inflammatory condition [38]. The widespread gliosis and increased levels of numerous inflammatory factors, including, but not-limited to, chemokines, cytokines, and acute phase reactants, in the absence of overt lymphocytic or mononuclear infiltrates is consistent with inflammation resulting from innate immune activation and not adaptive immune responses. In $A D$, the inflammatory changes are noted in the earliest stages of the disease process and have also been shown to be early events in some of the AD mouse models of amyloid and tau pathology. As noted above, in some cases the earliest pathology noted is microglial activation and increased levels of select cytokines [38,48-51]. Though often more focal in nature, inflammation is a hallmark of other CNS proteinopathies and is often seen as an early change in mouse models of these diseases [57].

Recent studies have revealed a remarkable connection between inflammatory mediators and replicative senescence [58-64]. These studies demonstrate that a hallmark of replicatively senescent cells is a massive increase in the secretion of multiple pro-inflammatory proteins, including IL-6, IL-8 (CXCL8), IL-1 $\alpha$ and $\beta$ and monocyte chemoattractant peptide-1 (MCP-1, CCL2) [60,63]. In certain cases it has been shown that these secreted proteins can act in an autocrine manner to further maintain the senescent state, drive senescence of neighboring cells in a paracrine fashion, and promote degenerative or proliferative changes in neighboring cells $[58,60]$. It has also been shown that key inflammatory pathways, including those mediated by IL- 6 and CXCR2 ligands, are not only upregulated by senescence but may play a critical role in inducing and maintaining senescence [59,62-64]. Notably IL-6 and MCP-1 are markedly upregulated in $A D$, as are CXCR2 receptors [38,65-71]. Finally, it is well-established that oxidative stress, which almost invariably accompanies chronic inflammation, can also induce senescence [72-74]. Oxidative stress can also arise independently of inflammatory pathways in CNS proteinopathies [75]. Extracellular $A \beta$ has been reported to directly cause oxidative stress through production of reactive oxygen species [76,77]. Oxidative stress arising from mitochondrial dysfunction has also been reported to be associated with numerous neurodegenerative proteinopathies [75]. Thus, senescence appears to be associated with an induction of a pro-inflammatory state, but can also result from an inflammatory state. Moreover, inflammatory mediators and oxidative stress can synergistically act to drive senescence.

\section{Step 4: senescence and neurodegeneration}

Senescence has largely been studied in the context of dividing cells, a phenomenon more specifically referred to as replicative senescence. Replicative senescence was first described by Hayflick, and the 'Hayflick limit' refers to the limited replicative capacity of primary human fibroblasts or other diploid cell lines to prolonged passaging in tissue culture [78]. Typically, such senescence results in cells with altered morphology (large, flattened cells with high cytoplasm to nucleus ratios), telomere shortening or telomerase malfunction, distinct senescenceassociated hetrochromatic foci, and increased expression of a panel of senescence-associated biomarkers (for example, senescence-associated $\beta$-galactosidase activity, INK4A, IL-6) $[58,60,79]$. A functional definition is that a senescent cell has lost its replicative capacity and is no longer able to respond to growth factors. Though replicative senescence has been postulated to be a key driver of human aging, it is more likely that replicative senescence is simply one of many factors that contribute to the aging process. 
To date there has been very little study of senescence of neurons or even glia cells. As neurons are terminally differentiated, it is immediately obvious that one of the critical hallmarks of replicative senescence, inability to divide, does not apply. Some would claim that because they are terminally differentiated, neurons cannot senesce [80]. However, we postulate that neurons do undergo physiological senescence and that this senescence is accelerated in AD and other CNS proteinopathies by inflammatory and oxidative stimuli. Moreover, we postulate that a senescent neuron will be defined functionally by its inability to respond appropriately to growth factors and its expression of senescence-associated proteins. In this scenario, other CNS cells, including glia, neuroglial stem cells, and endothelial and smooth muscle cells that form the cerebrovasculature, are also likely to undergo senescent changes in response to the chronic inflammatory environment. Senescent astrocytes might switch from a neuroprotective phenotype to one that is less suitable for supporting neuronal homeostasis. Senescence of microglia cells has been proposed as a mechanism for 'aging' microglia, less efficient scavenger cells with diminished phagocytic capacity and enhanced neurotoxic potential $[81,82]$. Put simply, we postulate that CNS cells will display a senescent phenotype that is physiologically similar to cells that have undergone replicative senescence, and be functionally impaired in a way that leads to neuronal dysfunction and degeneration. Ultimately, a growing number of senescent cells will lead to either widespread brain 'organ failure' as exhibited in $A D$, or more or less regional brain organ failure as seen in other neurodegenerative proteinopathies.

One of the key features of this hypothesis is that once triggered by the proteinopathy, senescent changes are likely to be both self-reinforcing and irreversible. In an autocrine fashion, inflammatory mediators secreted by the senescent neurons and glia would help to maintain the senescent state [60]. In a paracrine fashion, senescent cells induce additional inflammation and senescence of neighboring cells. Over long periods of time senescent neurons become increasingly dysfunctional and die due to a combination of diminished response to growth factors and possible pathophysiological effects of chronic exposure to an altered milieu of signaling factors as well as the direct signaling effects of the protein aggregates. Senescent changes can also affect neuronal stem cells, leading to diminished potential for renewal of neurons.

It is likely that the senescence response is not an 'all or none' phenomenon. There may be a graded continuum of responses to a proteinopathy-induced stress that depends both on the strength and acuteness of the stress as well as the preprogrammed response of the cell. Experimental data demonstrate that cells with high levels of anti-apoptotic proteins often undergo senescence whereas cells with lower levels of anti-apoptotic factors seem prone to undergo apoptosis [83-85]. Mature neurons, which are known to express high levels of anti-apoptotic proteins, may respond to potentially apoptotic stresses by senescing. At least in culture, a lower level of oxidative stress can drive senescence whereas a higher level can drive apoptosis. The notion that cellular 'stress', depending on the context, can result in two different endpoints, either apoptosis or senescence, may help to explain the disparate endpoints observed in various neurodegenerative proteinopathy models. In models where the cells are 'primed' to undergo apoptosis, a proteinopathydriven stress will more likely drive apoptosis. In models where the proteinopathy is overwhelming, apoptosis may also be the primary endpoint. If the proteinopathy develops more insidiously, senescence may result.

Of course there is extensive neuronal loss in AD. So how would a senescent cell die? Senescent cells are stable for some period of time, and little information has been published on how they die. As noted above, in vitro studies suggest that senescence is an alternative pathway to apoptosis and that senescent cells are resistant to apoptosis. Of note, a recent study has shown that senescent keratinocytes die by autophagic cell death, a cell death pathway characterized by an increase in macroautophagic activity [86]. In many neurodegenerative diseases autophagic cell death has been implicated as an alternative to apoptotic or necrotic mechanisms $[45,87]$.

A more speculative extension of this hypothesis in $A D$ is that the senescent phenotype could be the key link between $A \beta$ proteinopathy and secondary proteinopathies that are seen in the $A D$ brain, including those involving tau, $\alpha$-synuclein and TDP-43. At least for tau and $\alpha$-synuclein there is experimental evidence that an $A \beta$ proteinopathy can enhance, if not trigger, a tauopathy or synucleinopathy. Despite intense investigation, there is no consensus regarding the pathways that relay the signals between $A \beta$ and tau, synuclein, or TDP-43. Although it is possible that we simply have not identified the single critical factor, it is perhaps more likely that $A \beta$ proteinopathy induces a plethora of changes that drive the secondary proteinopathies. Given that senescence triggers gross changes in the transcriptome and secretome, perhaps senescent changes mediate the secondary proteinopathy?

\section{Future studies: how do we prove that the AD brain is senescing?}

Recent studies of the senescence-associated secretory phenotype (SASP), also termed the senescence-messaging secretome (SMS), have identified a number of secreted biomarkers associated with replicative senescence $[58,60$, 63]. Depending on the cell type examined, the method of induction of senescence, and the methodology used to identify the secreted proteins, the secretome and transcriptome that defines the SASP/SMS can be variable. However, certain proteins are invariably identified in these studies. Many of the proteins consistently upregulated during senescence are inflammatory mediators, including IL-6, IL-8 and other chemokines and cytokines $[58,60,63]$. Though not 
Table 1

Senescence-associated secretory phenotype/senescence messaging secretome biomarkers in Alzheimer's disease

\begin{tabular}{|c|c|c|}
\hline Protein & Alteration(s) in $\mathrm{AD}^{\mathrm{a}}$ & Association with senescence \\
\hline IL-6 & $\uparrow$ in $B, C, P[65,71,120]$ & $\begin{array}{l}\uparrow \text { in oncogene-induced senescence (OIS); mediates the SASP in vitro; } \\
\text { knockdown results in senescence bypass }[59,63]\end{array}$ \\
\hline $\begin{array}{l}\text { IL-8 (CXCL8) and other } \\
\text { CXCR2 ligands/CXCR2 }\end{array}$ & $\begin{array}{l}\uparrow \mathrm{IL}-8 \text { in } \mathrm{B}, \mathrm{C}, \mathrm{P}, \text { focal } \uparrow \mathrm{CXCR} 2 \text { in } \mathrm{B} \\
\text { in plaque-associated dystrophic } \\
\text { neurites }[66,68,69]\end{array}$ & $\begin{array}{l}\uparrow I L-8 \text { and other CXCR2 ligands in multiple in vitro models of } \\
\text { replicative senescence; CXCR2 signaling functionally implicated in } \\
\text { replicative senescence }[59,63,64]\end{array}$ \\
\hline MCP-1 & $\uparrow$ in $B[65]$ & $\uparrow$ in vitro in multiple models of replicative senescence \\
\hline IL $1-\alpha$ & $\begin{array}{l}\downarrow \text { in } P[71], \cong P[121,122] \\
\uparrow \text { mRNA in } B[123]\end{array}$ & Implicated in endothelial cell senescence $[124,125]$ \\
\hline ICAM-1 & $\uparrow$ in $B, P[71,126-128]$ & $\uparrow$ in vitro in replicative senescence [63] \\
\hline IGFBP & $\begin{array}{l}\uparrow \text { IGFPB6 in P [71], } \uparrow \text { IGFPB2 } \\
\text { and } 6 \text { in } C[129]\end{array}$ & $\begin{array}{l}\text { Various IGFBP } \uparrow \text { in replicative senescence; IGFBP sufficient and } \\
\text { required for replicative senescence in various models [130-133] }\end{array}$ \\
\hline GM-CSF & $\cong$ to $\uparrow$ in $C[134,135]$ & $\uparrow$ in vitro in replicative senescence [63] \\
\hline Osteoprotegerin & $\uparrow$ in $P[136]$ & $\uparrow$ in vitro in replicative senescence [63] \\
\hline PAl-1 & $\begin{array}{l}\text { CNS homolog neuroserpin } \uparrow \text { in } B \\
\text { [137] }\end{array}$ & $\begin{array}{l}\uparrow \text { in vitro in models of replicative senescence and critical for induction } \\
\text { [138] }\end{array}$ \\
\hline TGF- $\beta$ & $\uparrow$ in $\mathrm{B}, \mathrm{C}, \mathrm{P}[38,139]$ & $\begin{array}{l}\uparrow \text { in vitro in multiple models of replicative senescence; implicated in } \\
\text { inducing replicative senescence }[140,141]\end{array}$ \\
\hline WNT2 & $\begin{array}{l}\text { Wnt pathway implicated in } \\
\text { pathogenic signaling cascades in } \\
\text { AD. No rigorous biomarker studies. } \\
\text { A } \beta \text { implicated as blocking Wnt } \\
\text { signaling [142] }\end{array}$ & $\downarrow$ WNT2 in replicative senescence and OIS [143] \\
\hline sPLA2/sPLA2R & $\begin{array}{l}\uparrow \text { group IV isoform of phospholipase } \\
A(2) \text { in } B \text { [144] }\end{array}$ & $\begin{array}{l}\uparrow \text { sPLA2/sPLA2R in replicative senescence; sPLA2 (PLA2G2A) can } \\
\text { induce senescence in vitro [145] }\end{array}$ \\
\hline IGF-1 & $\begin{array}{l}\text { Some reports indicate } \uparrow \text { in AD brain } \\
\text { [146] }\end{array}$ & Linked to life-span extension $[58,60]$ \\
\hline MMPs & Various MMPs $\uparrow$ in $B$ and $P$ [147] & MMP3 $\uparrow$ associated with replicative senescence [148] \\
\hline
\end{tabular}

aB, brain; C, cerebrospinal fluid; $P$, plasma. Up and down arrows indicate increased and decreased levels, respectively. AD, Alzheimer's disease; CNS, central nervous system; GM-CSF, granulocyte-macrophage colony stimulating factor; ICAM, intracellular adhesion molecule; IGF, insulin-like growth factor; IGFBP, insulin-like growth factor binding protein; IL = interleukin; MCP, monocyte chemoattractant peptide; MMP, matrix metalloproteinase; OIS, oncogene-induced senescence; PAI, plasminogen activator inhibitor; sPLA2, soluble phospholipase A2; SASP, senescence-associated secretory phenotype; sPLA2R, soluble phospholipase A2 receptor; TGF, transforming growth factor.

a perfect correlation, there is extensive overlap between the biomarkers that comprise the core SASP/SMS phenotype and secreted biomarkers of AD (Table 1). This overlap provides evidence for a SASP/SMS in the AD brain, with many of these features seen in mouse models of AD. At least in $A D$, it has been challenging to define the nature of the 'immune-system dysregulation' based on pathway-type analyses; the overlap between the SAPS/SMS and biomarkers of $A D$ suggest that the 'immune-system dysregulation' may, in fact, reflect senescence [71].

Given the large number of inflammatory proteins that have been implicated in the SASP/SMS, one of the challenges in moving forward is to discriminate between 'classic' reactive neuroinflammation and senescence in the diseased brain. If one uses replicative senescence as a guide, the key observations that would distinguish a senescence from an inflammatory phenotype are: that inflammatory mediators are expressed by cells such as neurons that do not normally produce them; that neurons and other cells in the AD brain exhibit cytoplasmic and nuclear markers of senescence; and that the cells displaying these markers of senescence are both functionally impaired and exhibit a SASP/SMS phenotype. The links between senescence and inflammation could also be evaluated through a number of experimental paradigms. For example, does overexpression of inflammatory factors, such as IL-6 in the brain, drive senescent markers in CNS cells? Does forced expression of classic inducers of senescence, such as P53 or INK4A, in adult neurons drive senescence and inflammation?

Though clearly there is much work to be done to move this hypothesis forward, there is sufficient evidence in the literature to make the case for further study. In the $A D$ brain 
Table 2

Cytoplasmic and nuclear protein biomarkers of senescence in Alzheimer's disease

\begin{tabular}{lll}
\hline Protein & Alteration(s) in AD & Association with senescence \\
\hline p53 & $\uparrow$ in neurons, astrocytes [149,150] & Constitutively active p53 can induce senescence [151,152] \\
INK4A (p16) & $\uparrow$ in neurons with NFT [153,154] & Activated in senescence [155,156] \\
$\begin{array}{l}\text { Senescence associated- } \\
\beta \text {-galactosidase }\end{array}$ & Not examined & Classic widely accepted biomarker of senescence [92] \\
Cylcins D, E & $\uparrow$ in neurons [157] & $\uparrow$ in endothelial cells and fibroblasts during senescence [158,159] \\
\hline
\end{tabular}

aSenescence associated- $\beta$-galactosidase is $\beta$-galactosidase activity detected at $\mathrm{pH} 6.0 . \mathrm{AD}$, Alzheimer's disease; NFT, neurofibrillary tangle.

neurons strongly stain for MCP-1 and IL-6, suggesting that these inflammatory mediators are being 'ectopically expressed', or at least dramatically upregulated, in cells that are not professional immune cells [65]. In addition, neurons stain and can be shown to actually express the mRNA for a number of other secreted inflammatory proteins $[37,38]$. Notably, some of the neuronal expression of inflammatory markers can be seen in mouse models of $A D$ and other neurodegenerative disorders $[48,88]$. Cytoplasmic or nuclear protein markers associated with senescent cells are often cell-cycle proteins, tumor suppressors, or cell-cycle regulators [80]. In AD and other neurodegenerative diseases there is often marked upregulation of cyclins, p53 and related proteins, and cyclindependent kinase inhibitors that have also been implicated in the senescent phenotype (Table 2) [89-91]. Often these markers are upregulated in tangle-bearing neurons. Notably, there are no reports about the presence of a widely used 'biomarker' of senescence, senescence associated $\beta$ galactosidase activity, in AD or any other neurodegenerative condition [92].

Changes in telomere length, telomere activity, and the presence of distinct heterochromatic nuclear bodies (called senescence-associated heterochromatic foci) are also wellestablished markers of replicative senescence [80,93]. However, given the terminally differentiated state of neurons, it is unclear whether these markers would be expected to be seen in physiological senescence of neurons in the AD brain, or even in any of the CNS cells. For example, even senescence-associated heterochromatic foci are typically only seen in human cells and have been much more difficult to demonstrate in mouse cells [94,95]. Furthermore, mouse cells can undergo replicative senescence without shortened telomeres [80]. Thus, it is clear that the nuclear biomarkers of human replicative senescence may not apply to studies of CNS senescence.

Autophagy represents an additional potential link between senescence and neurodegeneration. Altered autophagy has been implicated in $A D$ and many other neurodegenerative conditions $[45,96]$. Genetic removal of genes involved in autophagy results in neurodegeneration [97,98]. More generally, autophagy plays a key role in organismal aging and lifespan $[99,100]$. Genetic alterations that induce premature aging phenotypes are associated with autophagy induction. Autophagosomes accumulate in senescent fibroblasts [101]. In addition, it also has been shown that autophagy is an effector mechanism of replicative senescence [102]. It is activated during senescence, as are a subset of autophagyrelated genes, and inhibition of autophagy delays oncogeneinduced replicative senescence [103,104]. Finally, it has recently been postulated that autophagy is a key mechanism in immune responses to intracellular pathogens [105].

\section{Alternative theories}

The main working hypothesis in $A D$ and other CNS proteinopathies has been that some species of the aggregated misfolded protein are directly neurotoxic $[1-4,106]$. There have been many variations on the theme of the presumptive neurotoxic protein aggregate. In primary neuronal culture systems it has been possible to reproducibly demonstrate that a variety of protein aggregates cause some form of 'neurotoxicity'. For example, $A \beta$ aggregates ranging from oligomers (dimers, trimers, tetramers, dodecamers to 50 to 100-mers), soluble protofibrils, actively growing fibrils, to mature fibrils have been implicated as potential pathological entities in $A D[3,107-114]$. Despite this intense focus on finding the exact assembly that is the real 'neurotoxin', there is little, if any, consensus in the field regarding this issue, in large measure because it has been difficult to unequivocally demonstrate that some of the proposed misfolded neurotoxins exist in vivo. Given the considerable body of data showing that protein aggregates can be directly neurotoxic by causing calcium influx, altering synaptic plasticity, impairing axonal transport and mitochondrial function, or altering other homeostatic functions in the cell, we believe that direct neurotoxic effects of protein aggregates probably do play some role in $A D$ and other neurodegenerative diseases. However, we would argue that a slow degenerative phenotype is hard to reconcile with a direct toxic mechanism and that if indeed there were a 'smoking gun' aggregate that was directly neurotoxic, that it would likely show a much better and more consistent correlation with disease or disease progression than do any of the current aggregates. 
Organisms have developed many ways to adapt to stressful stimuli. In the mature nervous system a key adaptive mechanism is to try to keep largely irreplaceable neurons alive. One of the most remarkable examples of this is that pathogenic viruses can be cleared from neurons by activation of the innate and adaptive immune systems in a non-cytolytic fashion [115]. In the periphery this immune activation would typically result in significant collateral damage and killing of the infected cells. As noted previously, there is some evidence that, in response to stress, a cell can either undergo apoptosis or senescence [104]. Given that mature neurons have many mechanisms to protect them from apoptosis, we might speculate that the same stress that induces apoptosis in a primary embryonic neuronal culture may induce senescence in the intact mature CNS.

\section{Therapeutic implications}

Replicative senescence does not appear to be easily reversible [80]. In the few examples where replicative senescence has been reversed in culture, the reversal typically requires inactivation or downregulation of tumor suppressors [116,117]. Thus, from a therapeutic point of view, reversal of a replicatively senescent phenotype poses serious problems as it increases the likelihood for tumorigenesis. Indeed, it is generally thought that replicative senescence is a mechanism designed to suppress tumorigenesis. If cells in the AD or other neurodegenerative disease brain are physiologically senescent, it may be very challenging to reverse the senescent phenotype. Of course, an enhanced understanding of physiological neuronal or glial senescence may reveal distinct differences between replicative senescence and the physiological senescence of these specialized cells. Understanding whether such differences are present may reveal new therapeutic approaches to treat many neurodegenerative diseases.

Recognizing that proteinopathy-induced inflammation may drive senescence, and thereby induce neurodegeneration, reinforces therapeutic efforts designed to prevent the formation of or clear the proteinopathy and also potentially reveals new pathways that could be the focus of therapeutic efforts. In the former case, the rationale is obvious - prevent the proteinopathy and the downstream cascade is prevented. Of course, as discussed in recent reviews, this type of therapy targeting the trigger of the disease is likely to be much more effective as primary prevention and may have little therapeutic benefit once degeneration is entrenched $[5,118]$. If some aspects of the degenerative cascade downstream of the proteinopathy are self-reinforcing and difficult to reverse, then therapeutics aimed at the initiator of the cascade will almost certainly have limited benefit when administered once these downstream cascades have begun. In the latter case, the notion that the inflammatory and senescent phenotypes may be mutually reinforcing responses that are capable of inducing pathological changes in a paracrine fashion establishes a new framework for understanding the interplay between chronic neuroinflammation and neuronal dysfunction. Further elucidation of an inflammatory senescence network may reveal multiple new targets for intervention. In particular, novel anti-inflammatory approaches designed to reduce the paracrine effects of the SASP/SMS may limit the spread of a neurodegenerative process, and thereby limit the collateral damage caused by a proteinopathy.

\section{Summary: age, aging, senescence, and neurodegeneration}

The major risk factor for developing $A D$ and other neurodegenerative diseases is age. Because of this association many in the field have proposed that aging contributes to the risk for developing $A D$ and other neurodegenerative diseases. Often the semantic distinction between age and aging is not well-defined even by those who use the terms. We use the term aging to refer to distinct biological processes that are altered as an organism grows older, and age will simply be used to denote time. Though it remains possible, and even likely, that aging does contribute to the risk of developing $A D$ or other neurodegenerative conditions, genetic studies indicate that aging effects can be overcome. Essentially, the same neurodegenerative disease can be driven in a relatively young person by a genetic alteration that accelerates the induction of the proteinopathy. For example, when the polyglutamine expansion is large enough, Huntington's disease can occur in children [119].

As alluded to previously, replicative senescence has been implicated as a key component of the aging process. In the context of a neurodegenerative cascade we would propose that senescence of CNS cells is a reinforcing pathway downstream of a proteinopathy that can, in an autocrine and paracrine fashion, create an environment that results in aging of the brain. Indeed, senescence appears to reinforce both chronic inflammation and oxidative stress, two factors that are thought to play a key role in the aging process. This might explain why genetically driven early onset forms of $A D$ and other neurodegenerative diseases mimic late onset sporadic forms of the disease.

The proteinopathy-induced senescent cell hypothesis of $A D$ and neurodegenerative disease that we describe here provides a novel integrative intellectual framework for future studies of pathological cascades in $A D$ and other neurodegenerative diseases. Such studies may broaden our understanding of the phenotype of senescing cells and also identify novel therapeutic targets for the treatment or prevention of $A D$ and other neurodegenerative disorders.

\section{Competing interests}

TEG is a co-editor in chief of this journal, for which he receives an honorarium. He serves on the SAB for Alzheimer's disease for Élan Pharmaceuticals, and has received sponsored research support from Lundbeck and Myriad Genetics. He is an inventor on several patents related 
to gamma-secretase modulators and anti- $A \beta$ immune therapy. VMM has no conflicts.

\section{Acknowledgements}

This work was supported by grants from the NIA (AG18454,AG29866, AG25531) and NINDS (NS39072), the CART fund, and the Mayo Foundation for Medical Research.

\section{References}

1. Forman MS, Trojanowski JQ, Lee VM: Neurodegenerative diseases: a decade of discoveries paves the way for therapeutic breakthroughs. Nat Med 2004, 10:1055-1063.

2. Ross CA, Poirier MA: Protein aggregation and neurodegenerative disease. Nat Med 2004, 10(Suppl):S10-17.

3. Hardy J, Selkoe DJ: The amyloid hypothesis of Alzheimer's disease: progress and problems on the road to therapeutics. Science 2002, 297:353-356.

4. Williams AJ, Paulson HL: Polyglutamine neurodegeneration: protein misfolding revisited. Trends Neurosci 2008, 31:521528.

5. Golde TE: Disease modifying therapy for AD? J Neurochem 2006, 99:689-707

6. Golde TE, Eckman CB, Younkin SG: Biochemical detection of Abeta isoforms: implications for pathogenesis, diagnosis, and treatment of Alzheimer's disease. Biochim Biophys Acta 2000, 1502:172-187.

7. Lee VM, Goedert M, Trojanowski JQ: Neurodegenerative tauopathies. Annu Rev Neurosci 2001, 24:1121-1159.

8. Small SA, Duff $\mathrm{K}$ : Linking Abeta and tau in late-onset Alzheimer's disease: a dual pathway hypothesis. Neuron 2008, 60:534-542.

9. Benvenga S: Conformational mutations in neuroserpin and familial dementias. Lancet 2002, 360:1696.

10. Ghiso J, Révész T, Holton J, Rostagno A, Lashley T, Houlden $H$, Gibb G, Anderton B, Bek T, Bojsen-Møller M, Wood N, Vidal R, Braendgaard H, Plant G, Frangione B: Chromosome 13 dementia syndromes as models of neurodegeneration. Amyloid 2001, 8:277-284.

11. Glenner GG: Amyloid deposits and amyloidosis. N Engl J Med 1980, 302:1283-1292.

12. Hutton M: Molecular genetics of chromosome 17 tauopathies. Ann N Y Acad Sci 2000, 920:63-73.

13. von Bergen M, Barghorn S, Li L, Marx A, Biernat J, Mandelkow $\mathrm{EM}$, Mandelkow E: Mutations of tau protein in frontotemporal dementia promote aggregation of paired helical filaments by enhancing local beta-structure. J Biol Chem 2001, 276:4816548174.

14. Goedert $M$, Jakes R: Mutations causing neurodegenerative tauopathies. Biochim Biophys Acta 2005, 1739:240-250.

15. Takeda K, Kaisho T, Akira S: Toll-like receptors. Annu Rev Immunol 2003, 21:335-376.

16. McDermott MF, Tschopp J: From inflammasomes to fevers, crystals and hypertension: how basic research explains inflammatory diseases. Trends Mol Med 2007, 13:381-388.

17. Mond JJ, Lees A, Snapper CM: T cell-independent antigens type 2. Annu Rev Immunol 1995, 13:655-692.

18. Mond JJ, Vos Q, Lees A, Snapper CM: T cell independent antigens. Curr Opin Immunol 1995, 7:349-354.

19. Garcia KC, Teyton L, Wilson IA: Structural basis of T cell recognition. Annu Rev Immunol 1999, 17:369-397.

20. van der Merwe PA, Davis SJ: Molecular interactions mediating T cell antigen recognition. Annu Rev Immunol 2003, 21:659684

21. Lovitch SB, Unanue ER: Conformational isomers of a peptideclass II major histocompatibility complex. Immunol Rev 2005, 207:293-313.

22. Maji SK, Perrin MH, Sawaya MR, Jessberger S, Vadodaria K, Rissman RA, Singru PS, Nilsson KP, Simon R, Schubert D, Eisenberg D, Rivier J, Sawchenko P, Vale W, Riek R: Functional amyloids as natural storage of peptide hormones in pituitary secretory granules. Science 2009, 325:328-332.

23. Fowler DM, Koulov AV, Alory-Jost C, Marks MS, Balch WE, Kelly JW: Functional amyloid formation within mammalian tissue. PLoS Biol 2006, 4:e6.

24. Münch J, Rücker E, Ständker L, Adermann K, Goffinet C,
Schindler M, Wildum S, Chinnadurai R, Rajan D, Specht A, Giménez-Gallego G, Sánchez PC, Fowler DM, Koulov A, Kelly JW, Mothes W, Grivel JC, Margolis L, Keppler OT, Forssmann WG, Kirchhoff F: Semen-derived amyloid fibrils drastically enhance HIV infection. Cell 2007, 131:1059-1071.

25. Jankowsky JL, Slunt HH, Gonzales V, Savonenko AV, Wen JC, Jenkins NA, Copeland NG, Younkin LH, Lester HA, Younkin SG, Borchelt DR: Persistent amyloidosis following suppression of Abeta production in a transgenic model of Alzheimer disease. PLoS Med 2005, 2:e355.

26. Bacskai BJ, Kajdasz ST, Christie RH, Carter C, Games D, Seubert $P$, Schenk D, Hyman BT: Imaging of amyloid-beta deposits in brains of living mice permits direct observation of clearance of plaques with immunotherapy. Nat Med 2001, 7:369-372.

27. Brendza RP, Bacskai BJ, Cirrito JR, Simmons KA, Skoch JM, Klunk WE, Mathis CA, Bales KR, Paul SM, Hyman BT, Holtzman DM: Anti-Abeta antibody treatment promotes the rapid recovery of amyloid-associated neuritic dystrophy in PDAPP transgenic mice. J Clin Invest 2005, 115:428-433.

28. Prada CM, Garcia-Alloza M, Betensky RA, Zhang-Nunes SX, Greenberg SM, Bacskai BJ, Frosch MP: Antibody-mediated clearance of amyloid-beta peptide from cerebral amyloid angiopathy revealed by quantitative in vivo imaging. $J \mathrm{Neu}^{-}$ rosci 2007, 27:1973-1980.

29. Bence NF, Sampat RM, Kopito RR: Impairment of the ubiquitinproteasome system by protein aggregation. Science 2001, 292:1552-1555.

30. Venkatraman P, Wetzel R, Tanaka M, Nukina N, Goldberg AL: Eukaryotic proteasomes cannot digest polyglutamine sequences and release them during degradation of polyglutamine-containing proteins. Mol Cell 2004, 14:95-104.

31. Yamamoto A, Lucas JJ, Hen R: Reversal of neuropathology and motor dysfunction in a conditional model of Huntington's disease. Cell 2000, 101:57-66.

32. Zu T, Duvick LA, Kaytor MD, Berlinger MS, Zoghbi HY, Clark HB, Orr HT: Recovery from polyglutamine-induced neurodegeneration in conditional SCA1 transgenic mice. J Neurosci 2004, 24:8853-8861.

33. Koo EH, Lansbury PT Jr, Kelly JW: Amyloid diseases: abnormal protein aggregation in neurodegeneration. Proc Natl Acad Sci U S A 1999, 96:9989-9990.

34. Harper JD, Lansbury PT Jr: Models of amyloid seeding in Alzheimer's disease and scrapie: mechanistic truths and physiological consequences of the time-dependent solubility of amyloid proteins. Annu Rev Biochem 1997, 66:385-407.

35. Bitan G, Fradinger EA, Spring SM, Teplow DB: Neurotoxic protein oligomers - what you see is not always what you get. Amyloid 2005, 12:88-95.

36. Walsh DM, Selkoe DJ: Oligomers on the brain: the emerging role of soluble protein aggregates in neurodegeneration. Protein Pept Lett 2004, 11:213-228.

37. Salminen A, Ojala J, Kauppinen A, Kaarniranta K, Suuronen T: Inflammation in Alzheimer's disease: amyloid-beta oligomers trigger innate immunity defence via pattern recognition receptors. Prog Neurobiol 2009, 87:181-194

38. Akiyama H, Barger S, Barnum S, Bradt B, Bauer J, Cole GM, Cooper NR, Eikelenboom P, Emmerling M, Fiebich BL, Finch CE, Frautschy S, Griffin WS, Hampel H, Hull M, Landreth G, Lue L, Mrak R, Mackenzie IR, McGeer PL, O'Banion MK, Pachter J, Pasinetti G, Plata-Salaman C, Rogers J, Rydel R, Shen Y, Streit W, Strohmeyer R, Tooyoma I, et al:: Inflammation and Alzheimer's disease. Neurobiol Aging 2000, 21:383-421.

39. McGeer PL, McGeer EG: Innate immunity, local inflammation, and degenerative disease. Sci Aging Knowledge Environ 2002, 2002:re3.

40. Jennings GT, Bachmann MF: The coming of age of virus-like particle vaccines. Biol Chem 2008, 389:521-536.

41. Eikelenboom P, Rozemuller JM, van Muiswinkel FL: Inflammation and Alzheimer's disease: relationships between pathogenic mechanisms and clinical expression. Exp Neurol 1998, 154: 89-98.

42. Bolmont $T$, Haiss $F$, Eicke $D$, Radde R, Mathis CA, Klunk WE, Kohsaka S, Jucker M, Calhoun ME: Dynamics of the microglial/amyloid interaction indicate a role in plaque maintenance. J Neurosci 2008, 28:4283-4292.

43. Koenigsknecht-Talboo J, Meyer-Luehmann M, Parsadanian M, Garcia-Alloza M, Finn MB, Hyman BT, Bacskai BJ, Holtzman DM: 
Rapid microglial response around amyloid pathology after systemic anti-Abeta antibody administration in PDAPP mice. $J$ Neurosci 2008, 28:14156-14164.

44. Dickey CA, Kamal A, Lundgren K, Klosak N, Bailey RM, Dunmore J, Ash P, Shoraka S, Zlatkovic J, Eckman CB, Patterson C, Dickson DW, Nahman NS Jr, Hutton M, Burrows F, Petrucelli L: The high-affinity HSP90-CHIP complex recognizes and selectively degrades phosphorylated tau client proteins. J Clin Invest 2007, 117:648-658.

45. Martinez-Vicente M, Cuervo AM: Autophagy and neurodegeneration: when the cleaning crew goes on strike. Lancet Neurol 2007, 6:352-361.

46. Srivastava $P$ : Roles of heat-shock proteins in innate and adaptive immunity. Nat Rev Immunol 2002, 2:185-194.

47. Janeway CA Jr: How the immune system recognizes invaders. Sci Am 1993, 269:72-79.

48. Yoshiyama Y, Higuchi M, Zhang B, Huang SM, Iwata N, Saido TC, Maeda J, Suhara T, Trojanowski JQ, Lee VM: Synapse loss and microglial activation precede tangles in a P301S tauopathy mouse model. Neuron 2007, 53:337-351.

49. Yang Y, Varvel NH, Lamb BT, Herrup K: Ectopic cell cycle events link human Alzheimer's disease and amyloid precursor protein transgenic mouse models. J Neurosci 2006, 26:775-784.

50. Hwang D, Lee IY, Yoo H, Gehlenborg N, Cho JH, Petritis $B$ Baxter D, Pitstick R, Young R, Spicer D, Price ND, Hohmann JG, Dearmond SJ, Carlson GA, Hood LE. A systems approach to prion disease. Mol Syst Biol 2009, 5:252.

51. Björkqvist M, Wild EJ, Thiele J, Silvestroni A, Andre R, Lahiri N, Raibon E, Lee RV, Benn CL, Soulet D, Magnusson A, Woodman B, Landles C, Pouladi MA, Hayden MR, Khalili-Shirazi A, Lowdell MW, Brundin P, Bates GP, Leavitt BR, Möller T, Tabrizi SJ: A novel pathogenic pathway of immune activation detectable before clinical onset in Huntington's disease. J Exp Med 2008, 205:1869-1877.

52. Glabe CG: Structural classification of toxic amyloid oligomers. J Biol Chem 2008, 283:29639-29643.

53. Caughey B, Lansbury PT: Protofibrils, pores, fibrils, and neurodegeneration: separating the responsible protein aggregates from the innocent bystanders. Annu Rev Neurosci 2003, 26:267-298.

54. Sahara N, Maeda S, Takashima A: Tau oligomerization: a role for tau aggregation intermediates linked to neurodegeneration. Curr Alzheimer Res 2008, 5:591-598.

55. Walsh DM, Selkoe DJ: Deciphering the molecular basis of memory failure in Alzheimer's disease. Neuron 2004, 44:181193.

56. Hardy J: The amyloid hypothesis for Alzheimer's disease: a critical reappraisal. J Neurochem 2009, 110:1129-1134.

57. Zipp F, Aktas O: The brain as a target of inflammation: common pathways link inflammatory and neurodegenerative diseases. Trends Neurosci 2006, 29:518-527.

58. Young AR, Narita M: SASP reflects senescence. EMBO Rep 2009, 10:228-230.

59. Kuilman T, Michaloglou C, Vredeveld LC, Douma S, van Doorn R, Desmet CJ, Aarden LA, Mooi WJ, Peeper DS: Oncogeneinduced senescence relayed by an interleukin-dependent inflammatory network. Cell 2008, 133:1019-1031.

60. Kuilman T, Peeper DS: Senescence-messaging secretome: SMS-ing cellular stress. Nat Rev Cancer 2009, 9:81-94.

61. Michaloglou C, Vredeveld LC, Soengas MS, Denoyelle C, Kuilman T, van der Horst CM, Majoor DM, Shay JW, Mooi WJ, Peeper DS: BRAFE600-associated senescence-like cell cycle arrest of human naevi. Nature 2005, 436:720-724.

62. Coppe JP, Boysen M, Sun CH, Wong BJ, Kang MK, Park NH, Desprez PY, Campisi J, Krtolica A: A role for fibroblasts in mediating the effects of tobacco-induced epithelial cell growth and invasion. Mol Cancer Res 2008, 6:1085-1098.

63. Coppe JP, Patil CK, Rodier F, Sun Y, Munoz DP, Goldstein J, Nelson PS, Desprez PY, Campisi J: Senescence-associated secretory phenotypes reveal cell-nonautonomous functions of oncogenic RAS and the p53 tumor suppressor. PLoS Biol 2008, 6:2853-2868.

64. Acosta JC, O'Loghlen A, Banito A, Guijarro MV, Augert A, Raguz S, Fumagalli M, Da Costa M, Brown C, Popov N, Takatsu Y, Melamed J, d'Adda di Fagagna F, Bernard D, Hernando E, Gil J: Chemokine signaling via the CXCR2 receptor reinforces senescence. Cell 2008, 133:1006-1018.

65. Sokolova A, Hill MD, Rahimi F, Warden LA, Halliday GM, Shepherd CE: Monocyte Chemoattractant protein-1 plays a dominant role in the chronic inflammation observed in Alzheimer's disease. Brain Pathol 2008, 19:392-398.

66. Xia M, Hyman BT: GROalpha/KC, a chemokine receptor CXCR2 ligand, can be a potent trigger for neuronal ERK1/2 and PI-3 kinase pathways and for tau hyperphosphorylation-a role in Alzheimer's disease? J Neuroimmunol 2002, 122:55-64.

67. Xia MQ, Hyman BT: Chemokines/chemokine receptors in the central nervous system and Alzheimer's disease. J Neurovirol 1999, 5:32-41.

68. Xia M, Qin S, McNamara M, Mackay C, Hyman BT: Interleukin-8 receptor $B$ immunoreactivity in brain and neuritic plaques of Alzheimer's disease. Am J Pathol 1997, 150:1267-1274.

69. Horuk R, Martin AW, Wang Z, Schweitzer L, Gerassimides A, Guo H, Lu Z, Hesselgesser J, Perez HD, Kim J, Parker J, Hadley TJ, Peiper SC. Expression of chemokine receptors by subsets of neurons in the central nervous system. J Immunol 1997 158:2882-2890.

70. Galimberti D, Fenoglio C, Lovati C, Venturelli E, Guidi I, Corrà B, Scalabrini D, Clerici F, Mariani C, Bresolin N, Scarpini E.: Serum MCP-1 levels are increased in mild cognitive impairment and mild Alzheimer's disease. Neurobiol Aging 2006, 27:17631768

71. Ray S, Britschgi M, Herbert C, Takeda-Uchimura $Y$, Boxer A, Blennow K, Friedman LF, Galasko DR, Jutel M, Karydas A, Kaye JA, Leszek J, Miller BL, Minthon L, Quinn JF, Rabinovici GD, Robinson WH, Sabbagh MN, So YT, Sparks DL, Tabaton M, Tinklenberg J, Yesavage JA, Tibshirani R, Wyss-Coray T: Classification and prediction of clinical Alzheimer's diagnosis based on plasma signaling proteins. Nat Med 2007, 13:1359-1362.

72. Muller M: Cellular senescence: molecular mechanisms, in vivo significance, and redox considerations. Antioxid Redox Signal 2009, 11:59-98.

73. Courtois-Cox S, Jones SL, Cichowski K: Many roads lead to oncogene-induced senescence. Oncogene 2008, 27:28012809.

74. Passos JF, Von Zglinicki T: Oxygen free radicals in cell senescence: are they signal transducers? Free Radic Res 2006, 40: 1277-1283.

75. Mattson MP, Liu D: Energetics and oxidative stress in synaptic plasticity and neurodegenerative disorders. Neuromolecular Med 2002, 2:215-231.

76. Bush Al, Tanzi RE: The galvanization of beta-amyloid in Alzheimer's disease. Proc Natl Acad Sci U S A 2002, 99:73177319 .

77. Garcia-Alloza M, Dodwell SA, Meyer-Luehmann M, Hyman BT, Bacskai BJ: Plaque-derived oxidative stress mediates distorted neurite trajectories in the Alzheimer mouse model. $J$ Neuropathol Exp Neurol 2006, 65:1082-1089.

78. Hayflick L: The limited in vitro lifetime of human diploid cell strains. Exp Cell Res 1965, 37:614-636.

79. Campisi J, Dimri GP, Nehlin JO, Testori A, Yoshimoto K: Coming of age in culture. Exp Gerontol 1996, 31:7-12.

80. Campisi J, d'Adda di Fagagna F: Cellular senescence: when bad things happen to good cells. Nat Rev Mol Cell Biol 2007, 8:729-740.

81. Streit WJ, Braak H, Xue QS, Bechmann I: Dystrophic (senescent) rather than activated microglial cells are associated with tau pathology and likely precede neurodegeneration in Alzheimer's disease. Acta Neuropatho/ 2009, 118: 475-485.

82. Streit WJ: Microglial senescence: does the brain's immune system have an expiration date? Trends Neurosci 2006, 29: 506-510.

83. Nelyudova A, Aksenov N, Pospelov V, Pospelova T: By blocking apoptosis, $\mathrm{Bcl}-2$ in p38-dependent manner promotes cell cycle arrest and accelerated senescence after DNA damage and serum withdrawal. Cell Cycle 2007, 6:2171-2177.

84. Tombor B, Rundell K. Oltvai ZN: Bcl-2 promotes premature senescence induced by oncogenic Ras. Biochem Biophys Res Commun 2003, 303:800-807.

85. Rebbaa A, Zheng X, Chou PM, Mirkin BL: Caspase inhibition switches doxorubicin-induced apoptosis to senescence. Oncogene 2003, 22:2805-2811.

86. Gosselin K, Deruy E, Martien S, Vercamer C, Bouali F, Dujardin T, Slomianny C, Houel-Renault L, Chelli F, De Launoit Y, Abbadie C: 
Senescent keratinocytes die by autophagic programmed cell death. Am J Patho/ 2009, 174:423-435.

87. Yuan J, Lipinski M, Degterev A: Diversity in the mechanisms of neuronal cell death. Neuron 2003, 40:401-413.

88. Owens T, Wekerle H, Antel J: Genetic models for CNS inflammation. Nat Med 2001, 7:161-166.

89. Lee HG, Casadesus G, Zhu X, Castellani RJ, McShea A, Perry G, Petersen RB, Bajic V, Smith MA: Cell cycle re-entry mediated neurodegeneration and its treatment role in the pathogenesis of Alzheimer's disease. Neurochem Int 2009, 54:84-88.

90. Ueberham $U$, Arendt $\mathrm{T}$ : The expression of cell cycle proteins in neurons and its relevance for Alzheimer's disease. Curr Drug Targets CNS Neurol Disord 2005, 4:293-306.

91. Herrup $\mathrm{K}$, Yang Y: Cell cycle regulation in the postmitotic neuron: oxymoron or new biology? Nat Rev Neurosci 2007, 8: 368-378.

92. Itahana K, Campisi J, Dimri GP: Methods to detect biomarkers of cellular senescence: the senescence-associated betagalactosidase assay. Methods Mol Bio/ 2007, 371:21-31.

93. Narita M, Narita M, Krizhanovsky V, Nunez S, Chicas A, Hearn SA, Myers MP, Lowe SW: A novel role for high-mobility group a proteins in cellular senescence and heterochromatin formation. Cell 2006, 126:503-514.

94. Adams PD: Remodeling chromatin for senescence. Aging Cell 2007, 6:425-427.

95. Adams PD: Remodeling of chromatin structure in senescent cells and its potential impact on tumor suppression and aging. Gene 2007, 397:84-93.

96. Pickford F, Masliah E, Britschgi M, Lucin K, Narasimhan R, Jaeger PA, Small S, Spencer B, Rockenstein E, Levine B, Wyss-Coray T: The autophagy-related protein beclin 1 shows reduced expression in early Alzheimer disease and regulates amyloid beta accumulation in mice. $J$ Clin Invest 2008, 118:2190-2199.

97. Komatsu M, Waguri S, Chiba T, Murata S, Iwata J, Tanida I, Ueno T, Koike M, Uchiyama Y, Kominami E, Tanaka K: Loss of autophagy in the central nervous system causes neurodegeneration in mice. Nature 2006, 441:880-884.

98. Hara T, Nakamura K, Matsui M, Yamamoto A, Nakahara Y, SuzukiMigishima R, Yokoyama M, Mishima K, Saito I, Okano H, Mizushima N: Suppression of basal autophagy in neural cells causes neurodegenerative disease in mice. Nature 2006, 441: 885-889.

99. Vellai T: Autophagy genes and ageing. Cell Death Differ 2009, 16:94-102.

100. Galluzzi L, Morselli E, Vicencio JM, Kepp O, Joza N, Tajeddine N, Kroemer G: Life, death and burial: multifaceted impact of autophagy. Biochem Soc Trans 2008, 36:786-790.

101. Gerland LM, Peyrol S, Lallemand C, Branche R, Magaud JP, Ffrench $\mathrm{M}$ : Association of increased autophagic inclusions labeled for beta-galactosidase with fibroblastic aging. Exp Gerontol 2003, 38:887-895.

102. Young AR, Narita M, Ferreira M, Kirschner K, Sadaie M, Darot JF, Tavaré S, Arakawa S, Shimizu S, Watt FM, Narita M: Autophagy mediates the mitotic senescence transition. Genes Dev 2009, 23:798-803.

103. Galluzzi L, Vicencio JM, Kepp O, Tasdemir E, Maiuri MC, Kroemer G: To die or not to die: that is the autophagic question. Curr Mol Med 2008, 8:78-91.

104. Vicencio JM, Galluzzi L, Tajeddine N, Ortiz C, Criollo A, Tasdemir E, Morselli E, Ben Younes A, Maiuri MC, Lavandero S, Kroemer G: Senescence, apoptosis or autophagy? When a damaged cell must decide its path - a mini-review. Gerontology 2008, 54:9299.

105. Deretic V: Autophagy in innate and adaptive immunity. Trends Immunol 2005, 26:523-528.

106. Yankner BA: Mechanisms of neuronal degeneration in Alzheimer's disease. Neuron 1996, 16:921-932

107. Selkoe DJ: Alzheimer's disease: genes, proteins, and therapy. Physiol Rev 2001, 81:741-766.

108. Glabe CC: Amyloid accumulation and pathogensis of Alzheimer's disease: significance of monomeric, oligomeric and fibrillar Abeta. Subcell Biochem 2005, 38:167-177.

109. Tanzi RE: The synaptic Abeta hypothesis of Alzheimer disease. Nat Neurosci 2005, 8:977-979.

110. Klein WL, Stine WB Jr, Teplow DB: Small assemblies of unmodified amyloid beta-protein are the proximate neurotoxin in Alzheimer's disease. Neurobiol Aging 2004, 25:569-
580.

111. Lesne S, Koh MT, Kotilinek L, Kayed R, Glabe CG, Yang A, Gallagher $\mathrm{M}$, Ashe $\mathrm{KH}$ : A specific amyloid-beta protein assembly in the brain impairs memory. Nature 2006, 440:352-357.

112. Shankar GM, Li S, Mehta TH, Garcia-Munoz A, Shepardson NE, Smith I, Brett FM, Farrell MA, Rowan MJ, Lemere CA, Regan CM, Walsh DM, Sabatini BL, Selkoe DJ: Amyloid-beta protein dimers isolated directly from Alzheimer's brains impair synaptic plasticity and memory. Nat Med 2008, 14:837-842.

113. Klyubin I, Betts V, Welzel AT, Blennow $K$, Zetterberg $H$, Wallin A, Lemere CA, Cullen WK, Peng Y, Wisniewski T, Selkoe DJ, Anwyl $\mathrm{R}$, Walsh DM, Rowan MJ: Amyloid beta protein dimer-containing human CSF disrupts synaptic plasticity: prevention by systemic passive immunization. J Neurosci 2008, 28:4231-4237.

114. Lauren J, Gimbel DA, Nygaard HB, Gilbert JW, Strittmatter SM: Cellular prion protein mediates impairment of synaptic plasticity by amyloid-beta oligomers. Nature 2009, 457:1128-1132.

115. Binder GK, Griffin DE: Immune-mediated clearance of virus from the central nervous system. Microbes Infect 2003, 5:439448.

116. Beausejour CM, Krtolica A, Galimi F, Narita M, Lowe SW, Yaswen $\mathrm{P}$, Campisi J: Reversal of human cellular senescence: roles of the p53 and p16 pathways. EMBO J 2003, 22:4212-4222.

117. Dirac AM, Bernards R: Reversal of senescence in mouse fibroblasts through lentiviral suppression of p53. J Biol Chem 2003, 278:11731-11734.

118. Golde TE: The therapeutic importance of understanding mechanisms of neuronal cell death in neurodegenerative disease. Mol Neurodegener 2009, 4:8.

119. Walker FO: Huntington's disease. Lancet 2007, 369:218-228.

120. Engelhart MJ, Geerlings MI, Meijer J, Kiliaan A, Ruitenberg A, van Swieten JC, Stijnen T, Hofman A, Witteman JC, Breteler MM: Inflammatory proteins in plasma and the risk of dementia: the rotterdam study. Arch Neurol 2004, 61:668-672.

121. Cacabelos R, Franco-Maside A, Alvarez XA: Interleukin-1 in Alzheimer's disease and multi-infarct dementia: neuropsychological correlations. Methods Find Exp Clin Pharmacol 1991, 13:703-708.

122. Cacabelos R, Barquero M, Garcia $P$, Alvarez XA, Varela de Seijas $\mathrm{E}$ : Cerebrospinal fluid interleukin-1 beta (IL-1 beta) in Alzheimer's disease and neurological disorders. Methods Find Exp Clin Pharmacol 1991, 13:455-458.

123. Blalock EM, Geddes JW, Chen KC, Porter NM, Markesbery WR, Landfield PW: Incipient Alzheimer's disease: microarray correlation analyses reveal major transcriptional and tumor suppressor responses. Proc Natl Acad Sci US A 2004, 101: 2173-2178.

124. Maier JA, Voulalas $P$, Roeder D, Maciag T: Extension of the lifespan of human endothelial cells by an interleukin-1 alpha antisense oligomer. Science 1990, 249:1570-1574.

125. Hsu JY, Hsu MY, Sorger T, Herlyn M, Levine EM: Heparin/endothelial cell growth supplement regulates matrix gene expression and prolongs life span of vascular smooth muscle cells through modulation of interleukin-1. In Vitro Cell Dev Biol Anim 1999, 35:647-654.

126. Rentzos M, Michalopoulou M, Nikolaou C, Cambouri C, Rombos A, Dimitrakopoulos A, Kapaki E, Vassilopoulos D: Serum levels of soluble intercellular adhesion molecule-1 and soluble endothelial leukocyte adhesion molecule-1 in Alzheimer's disease. J Geriatr Psychiatry Neurol 2004, 17:225-231.

127. Verbeek MM, Otte-Holler I, Wesseling P, Ruiter DJ, de Waal RM: Differential expression of intercellular adhesion molecule-1 (ICAM-1) in the A beta-containing lesions in brains of patients with dementia of the Alzheimer type. Acta Neuropathol 1996, 91:608-615.

128. Verbeek MM, Otte-Holler I, Westphal JR, Wesseling P, Ruiter DJ, de Waal RM: Accumulation of intercellular adhesion molecule1 in senile plaques in brain tissue of patients with Alzheimer's disease. Am J Pathol 1994, 144:104-116.

129. Tham A, Nordberg A, Grissom FE, Carlsson-Skwirut C, Viitanen $M$, Sara VR: Insulin-like growth factors and insulin-like growth factor binding proteins in cerebrospinal fluid and serum of patients with dementia of the Alzheimer type. J Neural Transm Park Dis Dement Sect 1993, 5:165-176.

130. Kim KS, Seu YB, Baek SH, Kim MJ, Kim KJ, Kim JH, Kim JR: Induction of cellular senescence by insulin-like growth factor binding protein-5 through a p53-dependent mechanism. Mol 
Biol Cell 2007, 18:4543-4552.

131. Kim KS, Kim MS, Seu YB, Chung HY, Kim JH, Kim JR: Regulation of replicative senescence by insulin-like growth factor-binding protein 3 in human umbilical vein endothelial cells. Aging Cell 2007, 6:535-545.

132. Oh SH, Kim WY, Kim JH, Younes MN, El-Naggar AK, Myers JN, Kies M, Cohen P, Khuri F, Hong WK, Lee HY: Identification of insulin-like growth factor binding protein-3 as a farnesyl transferase inhibitor $\mathrm{SCH} 66336$-induced negative regulator of angiogenesis in head and neck squamous cell carcinoma. Clin Cancer Res 2006, 12:653-661.

133. Sprenger CC, Vail ME, Evans K, Simurdak J, Plymate SR: Overexpression of insulin-like growth factor binding proteinrelated protein-1(IGFBP-rP1/mac25) in the M12 prostate cancer cell line alters tumor growth by a delay in G1 and cyclin A associated apoptosis. Oncogene 2002, 21:140-147.

134. Tarkowski E, Andreasen N, Tarkowski A, Blennow K: Intrathecal inflammation precedes development of Alzheimer's disease. $J$ Neurol Neurosurg Psychiatry 2003, 74:1200-1205.

135. Tarkowski E, Wallin A, Regland B, Blennow K, Tarkowski A: Local and systemic GM-CSF increase in Alzheimer's disease and vascular dementia. Acta Neurol Scand 2001, 103:166-174.

136. Emanuele E, Peros E, Scioli GA, D'Angelo A, Olivieri C, Montagna L, Geroldi D: Plasma osteoprotegerin as a biochemical marker for vascular dementia and Alzheimer's disease. Int $\mathrm{J} \mathrm{Mol} \mathrm{Med}$ 2004, 13:849-853

137. Fabbro S, Seeds NW: Plasminogen activator activity is inhibited while neuroserpin is up-regulated in the Alzheimer disease brain. J Neurochem 2009, 109:303-315.

138. Kortlever RM, Higgins PJ, Bernards R: Plasminogen activator inhibitor-1 is a critical downstream target of p53 in the induction of replicative senescence. Nat Cell Biol 2006, 8:877-884.

139. Wyss-Coray T, Masliah E, Mallory M, McConlogue L, JohnsonWood K, Lin C, Mucke L: Amyloidogenic role of cytokine TGFbeta1 in transgenic mice and in Alzheimer's disease. Nature 1997, 389:603-606.

140. Tremain R, Marko M, Kinnimulki V, Ueno H, Bottinger E, Glick A: Defects in TGF-beta signaling overcome senescence of mouse keratinocytes expressing v-Ha-ras. Oncogene 2000, 19:1698-1709.

141. Glick AB, Lee MM, Darwiche N, Kulkarni AB, Karlsson S, Yuspa $\mathrm{SH}$ : Targeted deletion of the TGF-beta 1 gene causes rapid progression to squamous cell carcinoma. Genes Dev 1994, 8: 2429-2440.

142. Boonen RA, van Tijn P, Zivkovic D: Wnt signaling in Alzheimer's disease: up or down, that is the question. Ageing Res Rev 2009, 8:71-82

143. Ye X, Zerlanko B, Kennedy A, Banumathy G, Zhang R, Adams PD: Downregulation of Wnt signaling is a trigger for formation of facultative heterochromatin and onset of cell senescence in primary human cells. Mol Cell 2007, 27:183-196.

144. Sanchez-Mejia RO, Newman JW, Toh S, Yu GQ, Zhou Y, Halabisky B, Cissé M, Scearce-Levie K, Cheng IH, Gan L, Palop JJ, Bonventre JV, Mucke L: Phospholipase A2 reduction ameliorates cognitive deficits in a mouse model of Alzheimer's disease. Nat Neurosci 2008, 11:1311-1318.

145. Augert A, Payre C, de Launoit Y, Gil J, Lambeau G, Bernard D: The M-type receptor PLA2R regulates senescence through the p53 pathway. EMBO Rep 2009, 10:271-277.

146. Moloney AM, Griffin RJ, Timmons S, O'Connor R, Ravid R, O'Neill C: Defects in IGF-1 receptor, insulin receptor and IRS-1/2 in Alzheimer's disease indicate possible resistance to IGF-1 and insulin signalling. Neurobiol Aging 2008.

147. Baig S, Kehoe PG, Love S: MMP-2, -3 and -9 levels and activity are not related to Abeta load in the frontal cortex in Alzheimer's disease. Neuropathol Appl Neurobiol 2008, 34: 205-215.

148. Parrinello S, Coppe JP, Krtolica A, Campisi J: Stromal-epithelial interactions in aging and cancer: senescent fibroblasts alter epithelial cell differentiation. J Cell Sci 2005, 118:485-496.

149. Ohyagi Y, Asahara H, Chui DH, Tsuruta Y, Sakae N, Miyoshi K, Yamada T, Kikuchi $\mathrm{H}$, Taniwaki $\mathrm{T}$, Murai $\mathrm{H}$, lkezoe $\mathrm{K}$, Furuya $\mathrm{H}$, Kawarabayashi T, Shoji M, Checler F, Iwaki T, Makifuchi T, Takeda K, Kira J, Tabira T: Intracellular Abeta42 activates p53 promoter: a pathway to neurodegeneration in Alzheimer's disease. Faseb J 2005, 19:255-257.

150. Kitamura Y, Shimohama S, Kamoshima W, Matsuoka Y, Nomura
$\mathrm{Y}$, Taniguchi T: Changes of p53 in the brains of patients with Alzheimer's disease. Biochem Biophys Res Commun 1997, 232:418-421.

151. Itahana K, Dimri G, Campisi J: Regulation of cellular senescence by p53. Eur J Biochem 2001, 268:2784-2791.

152. Yaswen P, Campisi J: Oncogene-induced senescence pathways weave an intricate tapestry. Cell 2007, 128:233-234.

153. Arendt T, Rodel L, Gartner U, Holzer M: Expression of the cyclin-dependent kinase inhibitor p16 in Alzheimer's disease. Neuroreport 1996, 7:3047-3049.

154. McShea A, Harris PL, Webster KR, Wahl AF, Smith MA: Abnormal expression of the cell cycle regulators P16 and CDK4 in Alzheimer's disease. Am J Pathol 1997, 150:1933-1939.

155. Collins CJ, Sedivy JM: Involvement of the INK4a/Arf gene locus in senescence. Aging Cell 2003, 2:145-150.

156. Sharpless NE: Ink4a/Arf links senescence and aging. Exp Gerontol 2004, 39:1751-1759.

157. Busser J, Geldmacher DS, Herrup K: Ectopic cell cycle proteins predict the sites of neuronal cell death in Alzheimer's disease brain. J Neurosci 1998, 18:2801-2807.

158. Fukami-Kobayashi J, Mitsui Y: Cyclin D1 inhibits cell proliferation through binding to PCNA and cdk2. Exp Cell Res 1999, 246:338-347.

159. Lucibello FC, Sewing A, Brusselbach S, Burger C, Muller R: Deregulation of cyclins $D 1$ and $E$ and suppression of cdk2 and cdk4 in senescent human fibroblasts. J Cell Sci 1993, 105:123-133. 